BIOMEDICAL AND BIOSOCIAL ANTHROPOLOGY
$\begin{gathered}\text { Official Journal of the International Academy } \\ \text { of Integrative Anthropology } \\ \text { journal homepage: http://bba-journal.com }\end{gathered}$

\title{
Features of prevention of fetal growth retardation in pregnant women with chronic hypertension
}

Deinichenko O. V., Krut Yu. Ya., Izbytska N. G., Slinko O. M., Gaidai N. V., Pavlyuchenko M. I., Amro I. G., Puchkov V. A.

Zaporizhzhia State Medical University, Zaporizhzhia, Ukraine

\section{ARTICLE INFO}

Received: 23 September, 2019

Accepted: 24 October, 2019

UDC: $618.33-007.12:[618.3-$

06:616.12-008.331.1]]-084

\section{CORRESPONDING AUTHOR}

e-mail: agol0309@gmail.com Deinichenko O. V.
The lack of effective methods to prevent the development of fetal growth retardation in highrisk pregnant women remains a significant problem of modern obstetrics, which determines the relevance of the study. The aim of the study was to examine the effectiveness of monoprophylaxis of fetal growth retardation using aspirin at a dose of $150 \mathrm{mg}$, starting at 12-13 weeks of gestation, pregnant women with chronic hypertension. In order to apply and implement the proposed prevention of fetal growth retardation, all pregnant women with chronic hypertension were divided into two groups. The patients were divided into groups randomly. To prevent the development of fetal growth retardation, patients in group A received acetylsalicylic acid at $150 \mathrm{mg} /$ day, patients in group B received acetylsalicylic acid at 100 $\mathrm{mg} /$ day. Primary examination of pregnant women in a prospective study was performed during pregnancy 11-12 weeks in all groups, which included: history taking, general clinical examination, blood pressure measurement, obstetric and gynecological examination according to clinical protocols of the Ministry of Health of Ukraine № 417 from 15.07.2011, № 676 dated 31.12.2004. Clinical and instrumental examination was performed: blood pressure and ECG monitoring, Doppler examination. Childbirth and initial assessment of the condition of newborns were performed in accordance with the current orders of the Ministry of Health of Ukraine with the assessment of the condition on the Apgar scale and the result of anthropometry (determination of mass and growth rate). It was found that the age characteristics of the group of pregnant women did not differ statistically significantly: the average age of patients in group $A$ reached $27.3 \pm 1.6$ years, group $B-28.1 \pm 1.8$ years. According to the obstetric and gynecological history, the women did not differ. It should be noted that statistically significant differences between the main group and the comparison group by the degree of chronic hypertension (grade 1 and 2) were not detected: $30 \%$ of women in group $A$ and $35 \%$ of group $B$ had chronic hypertension grade $1,70 \%$ and $65 \%$, respectively - chronic arterial hypertension of 2 degrees. Among the concomitant lesions in pregnant women were determined: obesity 8 women of group $A$ (26.7\%), 8 people $(25.8 \%)$ of group B; varicose veins in 3 women (10.0\%) of group $A$, 4 people (12.9\%) of group $B$; pathology of the urinary system - in 2 cases (6.6\%) in group $A$ and in 2 people $(6.45 \%)$ of group $B$; pathology of the thyroid gland -2 women (6.6 \%) of group $A$, and 1 person (3.22\%) of group $B$, anemia of pregnant women - in 4 women (13.3\%) of group $A$, and 4 people $(12.9 \%)$ of group $B$; chronic viral hepatitis $C$ in remission in 1 woman of group $B(3.22 \%)$. As a result of the analysis of pregnancies and complications of childbirth, we found that the appointment of acetylsalicylic acid in addition to standard treatment of chronic arterial hypertension in accordance with clinical protocols at a dose of $150 \mathrm{mg} /$ day helped reduce the incidence of disorders of uteroplacental and fetal circulation by 2.7 times, fetal growth retardation - by 8,8 times and small to gestational age fetus - 4.8 times compared with the results of patients who received acetylsalicylic acid at a dose of $100 \mathrm{mg} /$ day. Keywords: pregnancy, chronic arterial hypertension, fetal growth retardation.

\section{Introduction}

In the structure of causes of perinatal morbidity and mortality, cardiovascular pathology ranks first among extragenital diseases $[10,11]$. Among these cardiovascular diseases, chronic hypertension occupies a leading place. 
The results of studies have shown that even moderate chronic hypertension, starting from the first trimester, poses an increased risk of cerebrovascular disorders and complications of normal pregnancy $[7,14,16,20]$. The basis of insufficiency in the mother-placenta-fetus system are changes in fetal and uterine-placental complexes with a violation of adaptive-compensatory mechanisms at the molecular, cellular and tissue levels, which contributes to the violation of transport, trophic, endocrine, metabolic and antitoxic function of the placenta. in the future - to fetal growth retardation [13].

Disorders of uteroplacental circulation are characterized by: impaired arterial blood flow and difficulty of venous outflow from the intervillous space, changes in the rheological and coagulation properties of maternal and fetal blood (hypercoagulation, hyperaggregation and increased viscosity); decreased capillary blood flow in the chorionic villi $[1,13,15]$. Nowadays, due to the lack of effective methods of prevention of fetal growth retardation, this problem remains relevant. This is due to the fact that the treatment of fetal growth retardation at a late stage of diagnosis, especially in severe cases of fetal growth retardation, is ineffective and does not solve the problem. Early diagnosis and early initiation of preventive measures are important $[2,5,6,10,18]$.

The aim of the research was to study the effectiveness of monoprophylaxis of fetal growth retardation using aspirin at a dose of $150 \mathrm{mg}$, starting from 12-13 weeks of pregnancy for pregnant women with chronic hypertension.

\section{Materials and methods}

In order to apply and implement the proposed comprehensive prevention of fetal growth retardation, all pregnant women with chronic hypertension were divided into two groups. The distribution of patients with chronic hypertension into groups $A$ and $B$ was performed randomly: each patient with odd laboratory values was assigned to group A (main group - 30 pregnant women with diagnosed chronic hypertension of 1-2 degrees), with even - to group $\mathrm{B}$ (comparison group - 31 pregnant women with diagnosed chronic arterial hypertension of 1-2 degrees), all patients received therapy according to the clinical protocol of the Ministry of Health of Ukraine.

To prevent the development of fetal growth retardation, patients in group A received acetylsalicylic acid at $150 \mathrm{mg} /$ day, patients in group $B$ received acetylsalicylic acid at 100 mg/day.

Criteria for inclusion in the study: pregnant women with diagnosed chronic arterial hypertension of the 1st degree; pregnant women with diagnosed chronic arterial hypertension of the 2 nd degree.

Criteria for exclusion of pregnant women from the study: diagnosed chronic stage III hypertension; diabetes; multiple pregnancy; the presence of chronic diseases in the pregnant woman in the stage of decompensation; severe infectious diseases (HIV infection, tuberculosis, syphilis, progressive viral hepatitis $B$ and $C$ ); chromosomal and genetic disorders; thrombophilia; perinatal infections; systemic connective tissue diseases; heart disease (defects, myocarditis); moderate or severe anemia; lung disease; oncological diseases; pregnancy that occurred with the help of assisted reproductive technologies.

The diagnosis of "chronic hypertension" was established in accordance with the recommendations of the Ukrainian Association of Cardiologists and the European Society of Cardiology for the treatment of hypertension, according to the current clinical protocol of the Ministry of Health of Ukraine № 676 from 31.12.2004. All pregnant women were examined by a physician, cardiologist. None of the study participants had contraindications to the appointment of the proposed drug prophylaxis.

Comprehensive clinical examination of patients included the study of obstetric and gynecological and somatic history, assessment of pregnancy, childbirth and the condition of the newborn, evaluation of clinical, laboratory and instrumental research methods.

Primary examination of pregnant women in a prospective study was performed during pregnancy 11-12 weeks in all groups, which included: history taking, general clinical examination, blood pressure measurement, obstetric and gynecological examination according to clinical protocols of the Ministry of Health of Ukraine № 417 from 15.07.2011, № 676 dated 31.12.2004. On the basis of "Regional perinatal center", Zaporizhzhia maternity hospital № 1 conducted clinical and instrumental examination: blood pressure monitoring and electrocardiography, Doppler examination.

Childbirth and initial assessment of the condition of newborns were performed in accordance with the current orders of the Ministry of Health of Ukraine with the assessment of the condition on the Apgar scale and the result of anthropometry (determination of mass and growth rate).

Chronic hypertension and fetal growth retardation were diagnosed according to the current clinical protocols of the Ministry of Health of Ukraine № 676 from 31.12.2004, № 782 from 29.12.2005. All pregnant women were examined by a physician, cardiologist.

Data on the results of examination and treatment of pregnant women were stored, processed and calculated by modern methods of analysis using the statistical package of the licensed program STATISTICA $® 13$ ("StatSoft", USA, № of license AXXR712D833214FAN5). The statistical significance of differences in groups in the assessment of qualitative indicators was determined using the criterion Chi-square $\left(\mathrm{X}^{2}\right)$ using the Yates correction.

\section{Results}

The age characteristics of the group of pregnant women did not differ statistically significantly: the average age of patients in group A reached 27.3 \pm 1.6 years, group B - 
Table 1. Data of obstetric and gynecological anamnesis of patients.

\begin{tabular}{|c|c|c|c|c|c|}
\hline \multirow{2}{*}{ Indicators } & \multicolumn{2}{|c|}{ A group, $\mathrm{n}=30$} & \multicolumn{2}{|c|}{ B group, $\mathrm{n}=31$} & \multirow{2}{*}{$\mathrm{p}$} \\
\cline { 2 - 5 } & abs. & $\%$ & abs. & $\%$ & \\
\hline 1st pregnancy & 11 & 36.7 & 12 & 40.0 & $>0.05$ \\
\hline 2nd pregnancy & 10 & 33.3 & 9 & 30.0 & $>0.05$ \\
\hline$>$ 2 pregnancy & 9 & 30.0 & 9 & 30.0 & $>0.05$ \\
\hline 1st childbirth & 13 & 43.3 & 13 & 43.3 & $>0.05$ \\
\hline 2nd childbirth & 12 & 40.0 & 11 & 36.7 & $>0.05$ \\
\hline$>$ 2 childbirths & 5 & 16.7 & 6 & 20.0 & $>0.05$ \\
\hline
\end{tabular}

Table 2. Frequency of pregnancy complications in groups of patients.

\begin{tabular}{|c|c|c|c|c|c|}
\hline \multirow{2}{*}{ Indicators } & \multicolumn{2}{|c|}{ A group, $\mathrm{n}=30$} & \multicolumn{2}{|c|}{ B group, $\mathrm{n}=31$} & \multirow{2}{*}{$\mathrm{p}$} \\
\cline { 2 - 5 } & abs. & $\%$ & abs. & $\%$ & \\
\hline Preeclampsia & 8 & 26.7 & 12 & 38.7 & $>0.05$ \\
\hline $\begin{array}{c}\text { Disorders of } \\
\text { uteroplacental } \\
\text { and fetal } \\
\text { circulation }\end{array}$ & 5 & 16.7 & 14 & 45.1 & $<0.05$ \\
\hline
\end{tabular}

Table 3. Frequency of fetal growth retardation in groups of patients.

\begin{tabular}{|c|c|c|c|c|c|}
\hline \multirow{2}{*}{ Indicators } & \multicolumn{2}{|c|}{ A group, $\mathrm{n}=30$} & \multicolumn{2}{|c|}{ B group, $\mathrm{n}=31$} & \multirow{2}{*}{$\mathrm{p}$} \\
\cline { 2 - 5 } & abs. & $\%$ & abs. & $\%$ & \\
\hline $\begin{array}{c}\text { Fetal growth } \\
\text { retardation }\end{array}$ & 1 & 3.3 & 9 & 29.0 & $<0.05$ \\
\hline
\end{tabular}

Table 4. Frequency of course, complications of pregnancy and childbirth in groups of patients.

\begin{tabular}{|c|c|c|c|c|c|}
\hline \multirow{2}{*}{ Indicators } & \multicolumn{2}{|c|}{ A group, $\mathrm{n}=30$} & \multicolumn{2}{|c|}{ B group, $\mathrm{n}=31$} & \multirow{2}{*}{$\mathrm{p}$} \\
\cline { 2 - 5 } & abs. & $\%$ & abs. & $\%$ & \\
\hline Premature birth & 1 & 3.3 & 3 & 9.6 & $>0.05$ \\
\hline $\begin{array}{c}\text { Cesarean } \\
\text { section }\end{array}$ & 3 & 10.0 & 6 & 19.3 & $>0.05$ \\
\hline $\begin{array}{c}\text { Small to } \\
\text { gestational age } \\
\text { fetus }\end{array}$ & 2 & 6.7 & 10 & 32.3 & $<0.05$ \\
\hline $\begin{array}{c}\text { False } \\
\text { contractions in } \\
\text { up to 37 weeks } \\
\text { of pregnancy }\end{array}$ & 4 & 13.3 & 9 & 29.0 & $>0.05$ \\
\hline $\begin{array}{c}\text { Fetal distress } \\
\text { during childbirth }\end{array}$ & 2 & 6.7 & 5 & 16.1 & $>0.05$ \\
\hline
\end{tabular}

$28.1 \pm 1.8$ years $(p>0.05)$. According to the obstetric and gynecological history, women did not differ (Table 1). It should be noted that statistically significant differences between the main group and the comparison group by the degree of chronic hypertension (1st and 2nd degree) were not detected: $30 \%$ of women in group $A$ and $35 \%$ in group $\mathrm{B}$ had chronic arterial hypertension of the 1 st degree, $70 \%$ and $65 \%$, respectively - chronic arterial hypertension of the 2nd degree $(p>0.05)$.

Among the concomitant lesions in pregnant women were determined: obesity in 8 women of group A $(26.7 \%)$, $8(25.8 \%)$ of group B ( $>0.05)$; varicose veins in 3 women $(10.0 \%)$ of group A and $4(12.9 \%)$ of group B ( $>0.05)$; pathology of the urinary system - in 2 cases $(6.6 \%)$ in group A and in $2(6.45 \%$ ) of group B ( $p>0.05)$; pathology of the thyroid gland - 2 women $(6.6 \%)$ of group $A$ and 1 $(3.22 \%)$ of group $B(p>0.05)$; anemia of pregnant women in 4 women $(13.3 \%)$ of group $A$ and $4(12.9 \%)$ of group $B$ ( $p>0.05)$; chronic viral hepatitis $C$ in remission in 1 woman of group B (3.22 \%) ( $p>0.05)$.

In pregnant women with chronic arterial hypertension of the 1st and 2nd degrees, preeclampsia was detected in about a third of women in both group $A$ and group $B$, but disorders of uteroplacental and fetal circulation were significantly less common in pregnant women in group $\mathrm{A}$ (Table 2).

Fetal growth retardation was also statistically significantly less common in patients of group A (Table 3 ).

The fetus was small before gestational age in 2 women of group $A$ and 10 in group $B(p<0.05)$. Other complications of childbirth did not differ in frequency in both groups of pregnant women $(p>0.05)$ (Table 4$)$.

\section{Discussion}

In the presence of extragenital pathology, in particular chronic arterial hypertension in pregnant women, treatment must include antihypertensive drugs. Clinical protocol of the Ministry of Health of Ukraine № 676 dated 31.12.2004 in the group of high-risk pregnant women regulates the use of methyldopa (central a2-blocker), clonidine (affects the neurogenic regulation of vascular tone), calcium channel blockers, selective $\beta 2$-adrenergic antagonist, calcium and use of aspirin in doses of $60-100 \mathrm{mg} /$ day from 20 weeks of pregnancy and before childbirth (improves the depth of placentation and blood circulation in the spiral arteries) $[4,12,17,18]$.

Despite the action of appropriate antihypertensive drugs, to reduce the risk of fetal growth retardation in pregnant women with chronic hypertension, such treatment is often insufficient due to a number of complications, including fetal growth retardation $[3,8,9,19]$. Thus, currently the search for effective methods to prevent the development of fetal growth retardation remains an urgent problem of modern obstetrics. The use of aspirin at a dose of $150 \mathrm{mg}$ up to 16 weeks of pregnancy is promising for women at increased risk, which reduces the likelihood of developing early preeclampsia and fetal growth retardation by $60-80$ $\%$, according to the recommendations of FIGO (2016).

As a result of the research, we did not find significant differences between the groups of patients of both groups by age, obstetric and gynecological history and the structure of the disease. It was found that daily use of aspirin 150 $\mathrm{mg} /$ day, started at 12-13 weeks of pregnancy, significantly reduces the incidence of uteroplacental and fetal circulation, fetal growth retardation and small to gestational age in pregnant women with chronic hypertension. The use of aspirin $150 \mathrm{mg} / \mathrm{day}$, reduced the incidence of preeclampsia, reduced the risk of sub- and decompensated placental insufficiency, which increased the frequency and timing of full-term pregnancy and made 
it possible to significantly reduce perinatal effects. The earlier the start of prophylaxis with aspirin at a dosage of $150 \mathrm{mg} / \mathrm{day}$, the more effective the prevention of preeclampsia and the development of fetal growth retardation in pregnant women with chronic hypertension.

It should be noted that these studies conducted at 1213 weeks of gestation had small groups, and we believe that large randomized controlled trials are needed to confirm our results. With the development of a method for predicting the high risk of fetal growth retardation, it will be possible to perform randomized trials to monitor groups at high risk of fetal growth retardation from early pregnancy and timely aspirin prevention. It remains unknown whether there is a

\section{References}

[1] Borzenko, I., Konkov, D., Kondratova, I., Basilayshvili, O., \& Gargin, V. (2019). Influence of endotheliopathy of spiral arteries on placental ischemia. Georgian medical news, 11(296), 131-134. PMID: 31889720

[2] Chang, Y., Chen, X., Cui, H. Y., Li, X., \& Xu, Y. L. (2017). New Predictive Model at $11+0$ to $13+6$ Gestational Weeks for EarlyOnset Preeclampsia With Fetal Growth Restriction. Reproductive Sciences, 24(5), 783-789. doi: 10.1177/ 1933719116669053

[3] Chistyakova, G. N., Remizova, I. I., Gazieva, I.A., \& Ustyantseva, L. S. (2015). Assessment of the state of the cardiovascular system of children born from women with chronic arterial hypertension. Pediatrics. journal them. G. N. Speransky, (2), 8-12.

[4] Cornette, J., Buijs, E. A., Duvekot, J. J., Herzog, E., Roos-Hesselink, J. W., Rizopoulos, D., ... \& Steegers, E. A. (2016). Hemodynamic effects of intravenous nicardipine in severely preeclamptic women with a hypertensive crisis. Ultrasound in Obstetrics \& Gynecology, 47(1), 89-95. doi: 10.1002/uog.14836

[5] Guedes-Martins, L. (2016). Chronic hypertension and pregnancy. In Hypertension: from basic research to clinical practice pp. 395-407). Springer, Cham.

[6] Morgan, J. L., Nelson, D. B., Roberts, S. W., Wells, C. E., Mclntire, D. D., \& Cunningham, F. G. (2016). Blood pressure profiles across pregnancy in women with chronic hypertension. American journal of perinatology, 33(12), 1128-1132. doi: 10.1055/s-0036-1584581

[7] O'Gorman, N., Nicolaides, K. H., \& Poon, L. C. (2016). The use of ultrasound and other markers for early detection of preeclampsia. Women's Health, 12(2), 199-207. doi: 10.2217/ whe.15.95

[8] Pineles, B. L., Crimmins, S., \& Turan, O. (2020). Timing of delivery in pregnancies complicated by suspected fetal growth restriction without Doppler abnormalities. American journal of perinatology, 37(06), 647-651. doi: 10.1055/s-0039-1688470

[9] Potapov, V. A., Syusyuka, V. G., Zharkikh, A. V., \& Plotnik, V. A. (2016). Mechanisms of adaptation of pregnant women with miscarriage in the dynamics of preserving therapy. Woman's health, 5(111), 77-82.

[10] Roos-Hesselink, J., Baris, L., Johnson, M., De Backer, J., Otto, C., Marelli, A., ... \& Parsonage, W. (2019). Pregnancy outcomes in women with cardiovascular disease: evolving trends over 10 years in the ESC Registry Of Pregnancy And Cardiac disease gestational age at which aspirin prophylaxis becomes ineffective, which is the subject of our further research.

\section{Conclusions}

As a result of analysis of pregnancies and complications of childbirth, we found that the appointment of acetylsalicylic acid in addition to standard treatment of chronic hypertension in accordance with clinical protocols at a dose of $150 \mathrm{mg} /$ day helped reduce the incidence of disorders of uteroplacental and fetal circulation by 2.7 times, fetal growth retardation - 8.8 times and small to gestational age fetus 4.8 times compared with the results of patients receiving acetylsalicylic acid at a dose of $100 \mathrm{mg} /$ day.

(ROPAC). European Heart Journal, 40(47), 3848-3855. doi: 10.1093/eurheartj/ehz136

[11] Sanghavi, M., \& Rutherford, J. D. (2014). Cardiovascular physiology of pregnancy. Circulation, 130(12), 1003-1008. doi: 10.1161/CIRCULATIONAHA.114.009029

[12] Seguro, F., Duly, B. B., Chamontin, B., \& Amar, J. (2016). Management of arterial hypertension before 20weeks gestation in pregnant women. Presse medicale (Paris, France: 1983), 45(7-8 Pt 1), 627-630.

[13] Sehgal, A., Murthi, P., \& Dahlstrom, J. E. (2019). Vascular changes in fetal growth restriction: clinical relevance and future therapeutics. Journal of Perinatology, 39(3), 366-374. doi: 10.1038/s41372-018-0287-4

[14] Selvaraj, L. R., Rose, N., \& Ramachandran, M. (2016). First trimester screening for pre-eclampsia and fetal growth restriction. Journal of Fetal Medicine, 3(2), 77-84. doi: 10.1007/ s40556-016-0088-9

[15] Thompson, L. P., Pence, L., Pinkas, G., Song, H., \& Telugu, B. P. (2016). Placental hypoxia during early pregnancy causes maternal hypertension and placental insufficiency in the hypoxic guinea pig model. Biology of reproduction, 95(6), 128-1. doi: 10.1095/biolreprod.116.142273

[16] Tsibulkin, N. A., Mayanskaya, S. D., \& Abdrakhmanova, A. I. (2010). Arterial hypertension during pregnancy. Practical medicine, 5(44), 32-35.

[17] Veropotvelian, P. N., Veropotvelian, N. P., Guzhevskaia, I. V., Tamamsheva, A. A., \& Tsekhmistrenko, I. S. (2013). Arterial hypertension in pregnant women and its correction. Women's health, (9), 58-65.

[18] Zamaleeva, R. S., Maltseva, L. I., Cherepanova, N. A., Frizina, A. V., Lazareva, V. K., lupatov, E. Yu., ... \& Fattakhova, F. A. (2016). State of the problem of treatment and prediction of fetal growth retardation. Practical medicine, 1(93), 41-44.

[19] Zamaleeva, R. S., Cherepanova, N. A., \& Gafarova, E. A. (2018). Modern concepts of treatment, prevention, diagnosis and prediction of fetal growth retardation. Remedium. Volga region, 2(162), 18-21.

[20] Zhu, J., Zhang, J., Ng, M. J., Chern, B., Yeo, G. S., \& Tan, K. H. (2019). Angiogenic factors during pregnancy in Asian women with elevated blood pressure in early pregnancy and the risk of preeclampsia: a longitudinal cohort study. BMJ open, 9(11), e032237. doi: 10.1136/bmjopen-2019-032237

\section{ОСОБЛИВОСТІ ПРОФІЛАКТИКИ РОЗВИТКУ ЗАТРИМКИ РОСТУ ПЛОДА У ВАГІТНИХ 3 ХРОНІЧНОЮ АРТЕРІАЛЬНОЮ ГІПЕРТЕНЗІєЮ}

Дейніченко О. В., Круть Ю. Я., Ізбицька Н. Г., Слинько О. М., Гайдай Н. В., Павлюченко М. І., Амро І. Г., Пучков В. А. Відсутність ефективних методів профрілактики розвитку затримки росту плода у вагітних високої групи ризику залишається 
значною проблемою сучасного акушерства, що визначає актуальність дослідження. Метою дослідження було вивчення ефрективності монопрофрілактики затримки росту плода з використанням аспірину у дозі 150 ме, починаючи з терміну вагітності 12-13 тижнів, вагітними з хронічною артеріальною гіпертензією. 3 метою застосування та впровадження запропонованої профрілактики виникнення затримки росту плода, усіх вагітних з хронічною артеріальною гіпертензією розподілили на дві групи. Розподіл пацієнток на групи виконували рандомізовано. Для профілактики розвитку затримки росту плода пацієнтки групи А отримували ацетілсаліцилову кислоту по 150 мг/добу, пацієнтки групи Б отримували ацетілсаліцилову кислоту по 100 мг/добу. Первинне обстеження вагітних жінок у проспективному дослідженні виконували в терміни вагітності 11-12 тижнів у всіх групах, яке включало: збір анамнезу, загально-клінічне обстеження, вимірювання артеріального тиску, виконання акушерсько-гінекологічного обстеження згідно клінічних протоколів МОЗ України № 417 від 15.07.2011, № 676 від 31.12.2004. Проводили клініко-інструментальне обстеження: моніторування артеріального тиску та ЕКГ, доплерометричне дослідження. Ведення пологів та первинну оцінку стану новонароджених проведено згідно чинних наказів МОз України з оцінкою стану за шкалою Апгар та результатом антропометрії (визначення масо-ростового показника). Встановлено, що за віковою

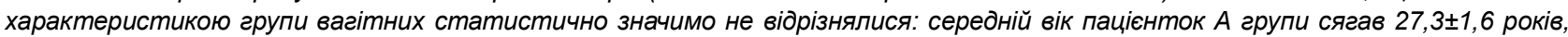
Б групи - 28,1士1,8 років. За даними акушерсько-гінекологічного анамнезу жінки не відрізнялися. Варто відзначити, що статистично значимих відмінностей між основною групою та групою порівняння за ступенем хронічної артеріальної гіпертензії (1 та 2 ступінь) не було виявлено: 30 \% жінок групи А та 35 \% групи Б мали хронічну артеріальну гіпертензію 1-го ступеня, 70 \% та 65 \%, відповідно - хронічну артеріальну гіпертензію 2-го ступеня. Серед супутніх уражень у вагітних визначалися: ожиріння 8 жінок групи A (26,7%), 8 осіб (25,8 \%) групи Б; варикозна хвороба у 3 жінок (10,0 \%) групи А, 4 осіб (12,9 \%) групи Б; патологія сечовидільної системи - у 2 випадках (6,6 \%) у групі А та у 2 осіб (6,45 \%) групи Б; патологія щитоподібної залози 2 жінки (6,6 \%) групи А та у 1 особи (3,22 \%) Б групи; анемія вагітних - у 4 жінок (13,3 \%) А групи та 4 осіб (12,9 \%) Б групи; хронічний вірусний гепатит С в стадії ремісії у 1 жінки Б групи (3,22 \%). В результаті проведеного аналізу перебігу вагітностей та виникнення ускладнень пологів нами було встановлено, що призначення ацетилсаліцилової кислоти додатково до стандартного лікування хронічної артеріальної гіпертензії відповідно до клінічних протоколів у дозі 150 мг/добу сприяло зменшенню частоти виникнення порушень матково-плацентарного та плодового кровообігу у 2,7 разів, затримки росту плода - у 8,8 разів та малого до гестаційного віку плоду - у 4,8 разів порівняно із результатами пацієнток, які отримували ацетилсаліцилову кислоту у дозі 100 мг/добу.

Ключові слова: вагітність, хронічна артеріальна гіпертензія, затримка росту плода.

\section{ОСОБЕННОСТИ ПРОФИЛАКТИКИ РАЗВИТИЯ ЗАДЕРЖКИ РОСТА ПЛОДА У БЕРЕМЕННЫХ С ХРОНИЧЕСКОЙ АРТЕРИАЛЬНОЙ ГИПЕРТЕНЗИЕЙ}

Дейниченко А. В., Круть Ю. Я., Избицкая Н. Г., Слинько О. М., Гайдай Н. В., Павлюченко М. И., Амро И. Г., Пучков В. А. Отсутствие эфрфективных методов профрилактики развития задержки роста плода у беременных высокой группы риска остается значительной проблемой современного акушерства, что определяет актуальность исследования. Целью исследования было изучение эфрфективности монопрофилактики задержки роста плода с использованием аспирина в дозе 150 ме, начиная со срока беременности 12-13 недель, беременными с хронической артериальной гипертензией. С целью применения и внедрения предложенной профрилактики возникновения задержки роста плода, всех беременных с хронической артериальной гипертензией разделили на две группы. Распределение пациенток на группы выполняли рандомизированно. Для профилактики развития задержки роста плода пациентки группы А получали ацетилсалициловую кислоту по 150 мг/сут, пациентки группы Б получали ацетилсалициловую кислоту по 100 мг/сут. Первичное обследование беременных женщин в проспективном исследовании выполняли в сроки беременности 11-12 недель во всех группах, которое включало: сбор анамнеза, клиническое обследование, измерение артериального давления, выполнение акушерско-гинекологического обследования согласно клиническим протоколам МОЗ Украины № 417 om 15.07.2011, № 676 om 31.12.2004. Проводили клиникоинструментальное обследование: мониторирование артериального давления и ЭКГ, допплерометрического исследования. Ведение родов и первичная оценка состояния новорожденных проведены согласно действующим приказам МОз Украины по оценке состояния плода по шкале Апгар и результатов антропометрии (определение массо-ростового показателя). Установлено, что по возрастной характеристике группы беременных статистически значимо не отличались: средний

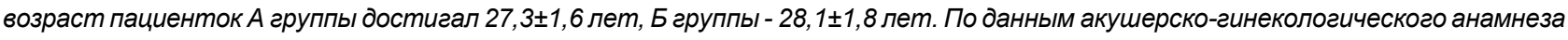
женщины не отличались. Стоит отметить, что статистически значимых различий между основной группой и группой сравнения по степени хронической артериальной гипертензии (1-я и 2-я степень) не было выявлено: 30 \% женщин группы $A$ и 35 \% группы Б имели хроническую артериальную гипертензию 1-ой степени, 70 \% и 65 \%, соответственно - хроническую артериальную гипертензию 2-ой степени. Среди сопутствующих поражений у беременных определялись: ожирение 8 женщин группы A (26,7%), 8 человек (25,8 \%) группы Б; варикозная болезнь у 3 женщин (10,0 \%) группы A, 4 человек (12,9 \%) группы Б; патология мочевыделительной системы - в 2 случаях (6,6 \%) в группе А и у 2 человек (6,45\%) группы Б; патология щитовидной железы - 2 женщины (6,6 \%) группы А и у 1 человека (3,22 \%) Б группы; анемия беременных - у 4 женщин (13,3 \%) A группы и 4 человек (12,9 \%) Б группы; хронический вирусный гепатит С в стадии ремиссии у 1 женщины Б группы (3,22 \%). В результате проведенного анализа течения беременностей и возникновения осложнений родов нами было установлено, что назначение ацетилсалициловой кислоты дополнительно к стандартному лечению хронической артериальной гипертензии в соответствии с клиническими протоколами в дозе 150 ма/сут способствовало уменьшению частоты нарушений маточноплацентарного и плодового кровообращения в 2,7 раза, задержке роста плода - в 8,8 раз и небольшого по отношению к гестационному возрасту плода - в 4,8 раз по сравнению с результатами пациенток, которые получали ацетилсалициловую кислоту в дозе 100 мг/сут.

Ключевые слова: беременность, хроническая артериальная гипертензия, задержка роста плода. 